\title{
EFFECT OF CROP ESTABLISHMENT METHOD AND NUTRIENT MANAGEMENT ON YIELD AND YIELD ATTRIBUTES OF SHORT DURATION T. AMAN RICE
}

\author{
L. Nahar*, A. B. S. Sarker, M. M. Mahbub and R. Akter \\ Bangladesh Rice Research Institute, Joydebpur, Gazipur-1701 \\ *Corresponding author, E-mail: lutfun.sau@gmail.com
}

(Received: 13 January 2018, Accepted: 1 February 2018)

Keywords: Crop establishment, nutrient management, yield and yield attributes

\begin{abstract}
A field trial was conducted at Agronomy Farm of Bangladesh Rice Research Institute to find out the effect of crop establishment method and nutrient management on yield performance of BRRI developed short-duration Aman rice var. BRRI dhan62 during July to October 2016. The trial comprised of four crop establishment methods viz., $\mathrm{M}_{1}=$ BRRI recommended puddle transplanting, $\mathbf{M}_{2}=$ System of rice intensification (SRI) method (9-days old seedling transplantation), $\mathbf{M}_{3}=$ Sprouted seed in line sowing and $\mathrm{M}_{4}=$ Sprouted seed in broadcasting and three nutrient management levels viz., $\mathrm{N}_{1}=\mathrm{BRRI}$ recommended nutrient management, $\mathrm{N}_{2}=$ Soil test-based nutrient management, $\mathrm{N}_{3}=$ Control. The study was conducted in a factorial Randomized Complete Block Design with three replications. The result showed that planting methods had significant effects on the yield of rice. The SRI method along with BRRI recommended fertilizer dose produced the maximum grain yield of $4.49 \mathrm{t} \mathrm{ha}^{-1}$ which was statistically similar with that produced in SRI method day- and soil test-based nutrient management combination. The highest gross margin (Tk. 36,308.00 ha-1) and cost benefit ratio (2.06) were observed in direct seeding of sprouted seed in line sowing method along with BRRI recommended fertilizer dose. So, direct seeding of sprouted seed in line could be a suitable planting method due to reduction of $26.0 \%$ production cost associated with seedling raising and transplanting operations.
\end{abstract}

\section{Introduction}

Rice (Oryza sativa L.) is a staple food of more than half of the world's population. In Bangladesh, rice covers $77 \%$ of the total cropped area (Quayum et al., 2012) and two third of the value added of the crop production. For rice cultivation different ways are followed in different rice growing agro-ecological zones of Bangladesh. Among them, mainly manual transplanting of seedlings into puddle soil is practiced in Bangladesh which means a process of cultivating soil in standing water, consumes a large quantity of labor. Chauhan et al., (2012) stated that sustainability of puddle transplanted rice (PTR) is threatened by increasing costs of production (especially labor) and due to increasing of agricultural labor scarcity which also delays crop establishment beyond the optimum time. Transplanting is a resource and cost intensive method since the preparation of seedbed, the raising of seedling and the transplanting are labor and time intensive operations. High labor involvement for these operations consists of nearly one third of the total cost of production in Bangladesh. To solve the high cost involvement technology, alternate methods of rice stand establishment are inevitable. Direct seeding of sprouted seed in wet soil would be another option to mitigate huge amount of human labor and time consumption. Direct seeding is more attractive than transplanting because it is cheaper and can result in an earlier harvest was stated by Balasubramanian and Hill, 2002. Direct seeded rice seedling does not subjected to stress like being pulled from the soil of the nursery and do not need to reproduce fine rootlets. Stoop et al. (2002) reported that young seedlings below 10 days of age are transplanted in SRI, which produce higher number of tillers 
than normal rice production systems, which contribute to higher grain yields (Krishna et al., 2009). In most Asian areas, the seedling age when transplanting to main field is about 25 to 30 days (IRRI, 1978). 15 and 40-day old seedlings had lower capability of stem elongation and tillering ability than 10-days old seedlings was observed by Kim et al. (1999).

Fertilizer is one of the most important management factors to increase the productivity of crops (FRG, 1997). Farmers are using higher amount of fertilizer for every crop without considering crop requirement causing imbalance in the system. Continuous degradation of soil health is caused due to imbalance use of chemical fertilizer and non-recycling of organic matter.

From the above circumstances, it is noted that BRRI dhan62 was a short duration high yielding Aman rice variety. So, the development of new rice variety may have a special adaptive capability under field conditions and can perform better under different nutrient management. For the above view, the performance of different seedling establishment methods and nutrient management practices on yield and yield attributes of Aman rice was evaluated.

\section{Materials and Methods}

An experiment was conducted at the Agronomy farm of Bangladesh Rice Research Institute, Gazipur-1701 belongs to AEZ-28, during the period from July to October 2016 to find out the effect of different rice seedling establishment methods and nutrient management on the yield and yield attributes of short duration Aman rice variety BRRI dhan62. Details of the soil analysis have been sown in Appendix I. Soil of the experimental field belongs to the Shallow Red Brown Terrace Soils. The experiential soil characters revealed that the soil was neutral having $\mathrm{pH} 6.64$, organic matter content was $(2.54 \%)$, total $\mathrm{N}(0.129 \%), \mathrm{P}(18.12 \mu \mathrm{g} / \mathrm{g})$, and S $(11.64 \mu \mathrm{g} / \mathrm{g})$ and $\mathrm{K}(0.10 \mathrm{meq} / 100 \mathrm{~g}$ of soil $)$. The soil nutrient content showed that organic matter was medium in level, N, S, K was low and whereas, $\mathrm{P}$ was optimum in level. The experiment comprised of four crop establishment methods Viz. $\mathrm{M}_{1}=$ BRRI recommended puddle transplanting, $\mathbf{M}_{2}=\mathrm{SRI}$ method (9-days old seedling transplantation), $\mathrm{M}_{3}=$ sprouted seed sown in line and $\mathrm{M}_{4}=$ sprouted seed by broadcasting method and three nutrient management package viz. $\mathrm{N}_{1}=\mathrm{BRRI}$ recommended dose of fertilizer, $\mathrm{N}_{2}=$ Soil test based recommended dose of fertilizer, and $\mathrm{N}_{3}=$ Control. On the basis of soil analysis data the exact fertilizer dose was calculated by using the following formula from FRG' 12 . The formula was

$$
\mathrm{F}_{\mathrm{r}}=\mathrm{U}_{\mathrm{f}^{-}} \mathrm{C}_{\mathrm{i}} / \mathrm{C}_{\mathrm{s}} \mathrm{X}\left(\mathrm{S}_{\mathrm{t}}-\mathrm{L}_{\mathrm{s}}\right)
$$

Where,

$\mathrm{F}_{\mathrm{r}}=$ Fertilizer nutrient require for given soil test value

$\mathrm{U}_{\mathrm{f}}=$ Upper limit of the recommended fertilizer nutrient for the respective STVI class

$\mathrm{C}_{\mathrm{i}}=$ unit of class intervals used for fertilizer nutrient recommendation

$\mathrm{C}_{\mathrm{S}}=$ unit of class intervals used for STVI class

$\mathrm{S}_{\mathrm{t}}=$ soil test value

$\mathrm{L}_{\mathrm{s}}=$ lower limit of the soil test value within STVI class

The experiment was conducted in a factorial Randomized Complete Block Design (RCBD) with three replications. The sprouted seeds were sown in line (line to line distance $20 \mathrm{~cm}$ ) and broadcasting methods in the assigned plots by manually on 29 July, 2016 and also sown in the nursery bed for raising seedling which was pre-pared previously. 25-day old seedlings were transplanted (2-3 seedlings hill $\left.{ }^{-1}\right)$ on 23 August 2016 with a spacing of $20 \mathrm{~cm} \times 20 \mathrm{~cm}$ while in SRI system 9-days old seedlings ( 1 seedling hill ${ }^{-1}$ ) were transplanted with a spacing $25 \mathrm{~cm} \times 25$ $\mathrm{cm}$ on 08 August 2016. Light irrigation was applied 4- 5 days after seeding to facilitate germination and plant establishment depending upon soil moisture in dry seeded plots. The experiment was conducted in rainfed condition but supplemental irrigation was applied as per 
necessary. According to BRRI recommended fertilizer was applied @ 200-62-83-56-5 kg ha-1 urea, triple super phosphate, muriate of potash, gypsum and zinc sulphate as per soil test based fertilizer was applied @ 113-32-116-46-5 $\mathrm{kg} \mathrm{ha}^{-1}$ urea, triple super phosphate, muriate of potash, gypsum and zinc sulphate. Entire quantity of all fertilizers except urea was applied as basal dose during final land preparation and mixed thoroughly with soil. Urea was top -dressed in three equal installments i.e., during sowing/transplanting, tillering stage and seven days before panicle initiation. All agronomic practices were performed uniformly for all the treatments. Two hand weedings were done at 30 and 50 DATs. Harvesting was done from 25 October 2016 to 01 November 2016 depending upon the maturity of the planting methods. Data were analyzed statistically for analysis of variance (ANOVA) following the method described by Gomez and Gomez (1984).

\section{Results and Discussion}

\section{Effect of crop establishment methods on yield and yield contributing characters}

Crop establishment techniques differed significantly in their ability to produce all variables (Table 1). BRRI recommended puddle transplanting $\left(\mathrm{M}_{1}\right)$ produced the maximum plant (111.4 $\mathrm{cm})$ that was statistically similar with SRI (9-days old seedling transplantation) $\left(\mathrm{M}_{2}\right)$ method. Sprouted seed sown in line $\left(\mathrm{M}_{3}\right)$ and broadcasting methods $\left(\mathrm{M}_{4}\right)$ produced statistically similar $(99.7 \mathrm{~cm}$ and $98.0 \mathrm{~cm})$ plant and comparatively shorter plant than other two treatments. Similarly, Hassan et al. (2011) was found that transplanting rice produced the tallest plant $(140.9 \mathrm{~cm})$ while direct seeding broadcasting and line sowing method produced the shortest $(128.1 \mathrm{~cm})$ and $(132.8 \mathrm{~cm})$ plant. In SRI system transplantation $\left(\mathrm{M}_{2}\right)$ produced the maximum number (245.0) of effective tillers $\mathrm{m}^{-2}$ followed by $\mathrm{M}_{1}$ method (229.0). Horie (2004) stated that practicing of transplanting one young seedling hill ${ }^{-1}$ with wider spacing (SRI) had advantages in reducing transplanting injury and increasing tiller. Hussain et al., (2004) also reported that SRI methods produced the highest number of effective tiller than farmers practice. Sprouted seed in line and broadcast sown methods produced the lowest number (217.0 and 199.0) of effective tillers $\mathrm{m}^{-2}$. Transplanting of SRI method $\left(\mathrm{M}_{2}\right)$ produced maximum number of filled grains panicle $^{-1}$ (99.0) followed by $\mathrm{M}_{1}$. The lowest number of filled grains panicle ${ }^{-1}$ (75.0) was recorded from $\mathrm{M}_{4}$. Hussain et al. (2004) observed higher number of grains panicle ${ }^{-1}$ under SRI compared to the farmers practice. The highest number of unfilled grains per panicle (27.0) was found in sprouted seed broadcasting methods followed by sprouted seed sown in line method. BRRI recommended (TPR) and SRI method (transplanting of 9 days old seedling) produced the lowest and statistically similar number of unfilled gain panicle. The highest thousand grain weight (22.3 g) was obtained from SRI method (9.0 days old seedlings) followed by BRRI recommended transplanting puddle rice and sprouted seed in line and broadcasting sowing method (Table 1). The transplantation of SRI method (9-days old seedling) produced higher grain yield $\left(3.85 \mathrm{t} \mathrm{ha}^{-1}\right)$ followed by BRRI recommended puddle transplanting. While sprouted seed in line and broadcasting methods produced the 3.56 and $2.98 \mathrm{t} \mathrm{ha}^{-1}$ grain yield, respectively. The increased straw yield $\left(5.34 \mathrm{ha}^{-1}\right)$ was obtained from SRI method (9- days old seedling) transplantation method than the puddle transplanting system. However, Husain et al. (2003) found 39\% higher straw yield in SRI compared to traditional methods while lowest straw yield $\left(4.60 \mathrm{t} \mathrm{ha}^{-1}\right)$ was obtained from sprouted seed broadcasting method.

Table 1. Effect of different crop establishment methods on yield and yield attributes of short duration Aman rice var. BRRI dhan62

\begin{tabular}{|c|c|c|c|c|c|c|c|}
\hline $\begin{array}{l}\text { Crop } \\
\text { establishment } \\
\text { methods }\end{array}$ & $\begin{array}{l}\text { Plant } \\
\text { height } \\
(\mathrm{cm})\end{array}$ & $\begin{array}{l}\text { Effective } \\
\text { tiller (m- } \\
\left.{ }^{2}\right)(\text { no. })\end{array}$ & $\begin{array}{c}\text { Filled } \\
\text { grain } \\
\text { panicle }^{-1} \\
\text { (no.) }\end{array}$ & $\begin{array}{l}\text { Unfilled } \\
\text { grain } \\
\text { panicle }^{-1} \\
\text { (no.) }\end{array}$ & $\begin{array}{c}1000- \\
\text { grain } \\
\text { weight. } \\
(\mathrm{g})\end{array}$ & $\begin{array}{l}\text { Grain } \\
\text { yield } \\
\left(\mathrm{t} \mathrm{ha}^{-1}\right)\end{array}$ & $\begin{array}{c}\text { Straw } \\
\text { yield } \\
\left(\mathrm{t} \mathrm{ha}^{-1}\right)\end{array}$ \\
\hline
\end{tabular}




\begin{tabular}{lccccccc}
\hline $\mathrm{M}_{1}$ & $111.4 \mathrm{a}$ & $229.0 \mathrm{~b}$ & $96.0 \mathrm{~b}$ & $20.0 \mathrm{c}$ & $21.9 \mathrm{~b}$ & $3.81 \mathrm{ab}$ & $5.20 \mathrm{a}$ \\
$\mathrm{M}_{2}$ & $110.8 \mathrm{a}$ & $245.0 \mathrm{a}$ & $99.0 \mathrm{a}$ & $20.0 \mathrm{c}$ & $22.3 \mathrm{a}$ & $3.85 \mathrm{a}$ & $5.34 \mathrm{a}$ \\
$\mathrm{M}_{3}$ & $99.7 \mathrm{~b}$ & $217.0 \mathrm{c}$ & $86.0 \mathrm{c}$ & $24.0 \mathrm{~b}$ & $21.9 \mathrm{bc}$ & $3.56 \mathrm{~b}$ & $4.82 \mathrm{~b}$ \\
$\mathrm{M}_{4}$ & $98.0 \mathrm{~b}$ & $199.0 \mathrm{~d}$ & $75.0 \mathrm{~d}$ & $27.0 \mathrm{a}$ & $21.5 \mathrm{c}$ & $2.98 \mathrm{c}$ & $4.60 \mathrm{c}$ \\
\hline $\mathrm{CV}(\%)$ & 4.59 & 6.64 & 3.34 & 9.34 & 1.69 & 5.16 & 3.74 \\
F-test & $* *$ & $* *$ & $* *$ & $* *$ & $* *$ & $* *$ & $* *$ \\
\hline
\end{tabular}

Note: $\mathrm{M}_{1}=\mathrm{BRRI}$ recommended transplanting puddle rice, $\mathrm{M}_{2}=\mathrm{SRI}$ method (9-days old seedling transplantation), $\mathrm{M}_{3}=$ Sprouted seed in line sowing, $\mathrm{M}_{4}=$ Sprouted seed in broadcasting

\section{Effect of nutrient management}

The plant height was statistically identical between BRRI recommended fertilizer dose $\left(\mathrm{N}_{1}\right)$ and Soil test based nutrient management $\left(\mathrm{N}_{2}\right)$ treatment, except control. Number of effective tillers $\mathrm{m}^{-2}$ was highest (237.0) with BRRI recommended fertilizer dose $\left(\mathrm{N}_{1}\right)$ that was at par with STB nutrient management $\left(\mathrm{N}_{2}\right)$. Similarly, Amin et al. (2004) was found that increased fertilizer dose of NPK increase number of total tillers plant ${ }^{-1}$. The control treatment produced the lowest (162.0) number of effective tiller. The maximum number (96.2) of filled grains panicle ${ }^{-1}$ was found with application of BRRI recommended fertilizer dose that was statistically similar with STB $+\left(\mathrm{N}_{2}\right)$ treatment. The control treatment $\left(\mathrm{N}_{3}\right)$ produced the lowest $(73.1)$ number of filled grains panicle ${ }^{-1}$. Consequently the control treatment produced the maximum number of unfilled grains panicle ${ }^{-1}$.

Table 2. Effect of different nutrient management practices on the yield and yield attributes of short duration Aman rice variety BRRI dhan62

\begin{tabular}{|c|c|c|c|c|c|c|c|}
\hline $\begin{array}{l}\text { Nutrient } \\
\text { management }\end{array}$ & $\begin{array}{l}\text { Plant } \\
\text { height } \\
(\mathrm{cm})\end{array}$ & $\begin{array}{l}\text { Effective } \\
\text { tiller (m } \\
2 \text { ) (no.) }\end{array}$ & $\begin{array}{c}\text { Filled } \\
\text { grain } \\
\text { panicle }^{-1} \\
\text { (no.) }\end{array}$ & $\begin{array}{l}\text { Unfilled } \\
\text { grain } \\
\text { panicle }^{-1} \\
\text { (no.) }\end{array}$ & $\begin{array}{l}\text { 1000- } \\
\text { grain } \\
\text { weight. } \\
(\mathrm{g})\end{array}$ & $\begin{array}{l}\text { Grain } \\
\text { yield } \\
\left(\mathrm{t} \mathrm{ha}^{-1}\right)\end{array}$ & $\begin{array}{c}\text { Straw } \\
\text { yield } \\
\left(\mathrm{t} \mathrm{ha}^{-1}\right)\end{array}$ \\
\hline $\mathrm{N}_{1}$ & $107.2 \mathrm{a}$ & $245.0 \mathrm{a}$ & $100.3 \mathrm{a}$ & $17.9 \mathrm{c}$ & $22.02 \mathrm{a}$ & $4.05 \mathrm{a}$ & $5.20 \mathrm{a}$ \\
\hline $\mathrm{N}_{2}$ & $107.2 \mathrm{a}$ & $239.0 \mathrm{~b}$ & $95.4 \mathrm{~b}$ & $20.0 \mathrm{~b}$ & $22.02 \mathrm{a}$ & $3.96 \mathrm{a}$ & $5.10 \mathrm{a}$ \\
\hline $\mathrm{N}_{3}$ & $100.8 \mathrm{~b}$ & $184.0 \mathrm{c}$ & $73.1 \mathrm{c}$ & $30.0 \mathrm{a}$ & $21.6 \mathrm{~b}$ & $2.63 \mathrm{~b}$ & $4.70 \mathrm{~b}$ \\
\hline $\mathrm{CV}(\%)$ & 4.59 & 6.64 & 3.34 & 9.34 & 1.69 & 5.16 & 3.74 \\
\hline F-test & $* *$ & $* *$ & $* *$ & $* *$ & * & ** & $* *$ \\
\hline
\end{tabular}

Note: $\mathrm{N}_{1}=$ BRRI recommended nutrient management, $\mathrm{N}_{2}=$ Soil test based nutrient management, $\mathrm{N}_{3}=$ Control

BRRI recommended nutrient management $\left(\mathrm{N}_{1}\right)$ and Soil test based nutrient management produced the maximum 1000 - grain weight $(\mathrm{g}),(22.02 \mathrm{~g})$ followed by $\mathrm{N}_{2}$ while the control treatment gave the lowest 1000-grain weight $(\mathrm{g})$. BRRI recommended nutrient management $\left(\mathrm{N}_{1}\right)$ produced the maximum grain yield $\left(4.05 \mathrm{t} \mathrm{ha}^{-1}\right)$ that was statistically similar with STB nutrient management $\left(3.96 \mathrm{t} \mathrm{ha}^{-1}\right)$. The control treatment produced the lowest grain yield $(2.63 \mathrm{t}$ $\left.\mathrm{ha}^{-1}\right)$. Straw yield $\left(\mathrm{t} \mathrm{ha}^{-1}\right)$ showed similar trends as in grain yield

\section{Interaction effect of crop establishment method and nutrient management}

Interaction effect of crop establishment methods and different nutrient management influenced significantly the studied parameters except plant height, number of unfilled grain panicle ${ }^{-1}$ and 1000-grain weight (Table 3). SRI method $\left(\mathrm{M}_{2}\right)$ along with BRRI recommended fertilizer dose $\left(\mathrm{N}_{1}\right)$ produced maximum number $(280.0)$ of effective tillers $\left(\mathrm{m}^{-2}\right)$ followed by combination of $\mathrm{M}_{2} \mathrm{~N}_{2}$. Sprouted seed in broadcasting method $\left(\mathrm{M}_{4}\right)$ along with control fertilizer $\left(\mathrm{N}_{3}\right)$ produced the lowest number (196.0) of effective tillers $\mathrm{m}^{-2}$. SRI system $\left(\mathrm{M}_{2}\right)$ along with BRRI recommended fertilizer dose $\left(\mathrm{N}_{1}\right)$ produced maximum (111.0) number of filled grains panicle ${ }^{-1}$ 
followed by treatment $\left(\mathrm{M}_{1}\right)$ along with BRRI recommended fertilizer doses $\left(\mathrm{N}_{1}\right)$ and soil test based fertilizer dose $\left(\mathrm{N}_{2}\right)$. The maximum grain yield $\left(4.49 \mathrm{t} \mathrm{ha}^{-1}\right)$ was obtained from SRI system (9-days old seedling) transplantation along with BRRI recommended fertilizer dose and STB fertilizer dose followed by BRRI recommended transplantation method. Sprouted seed in broadcasting system along with control fertilizer dose gave the minimum $\left(2.30 \mathrm{t} \mathrm{ha}^{-1}\right)$ grain yield. The straw yield of rice followed similar trend as in grain yield.

Table 3. Interaction effect of different crop establishment methods and nutrient management practices on the yield and yield attributes of short duration Aman rice variety BRRI dhan62

\begin{tabular}{|c|c|c|c|c|c|c|c|}
\hline Interaction & $\begin{array}{l}\text { Plant } \\
\text { height } \\
(\mathrm{cm})\end{array}$ & $\begin{array}{c}\text { Effective } \\
\text { tiller } \\
\left(\mathrm{m}^{-2}\right)(\text { no. })\end{array}$ & $\begin{array}{c}\text { Filled } \\
\text { grain } \\
\text { panicle }^{-1} \\
\text { (no.) }\end{array}$ & $\begin{array}{l}\text { Unfilled } \\
\text { grain } \\
\text { panicle }^{-1} \\
\text { (no.) }\end{array}$ & $\begin{array}{l}\text { 1000- } \\
\text { grain } \\
\text { wt. (g) }\end{array}$ & $\begin{array}{c}\text { Grain } \\
\text { yield } \\
\left(\mathrm{t} \mathrm{ha}^{-1}\right)\end{array}$ & $\begin{array}{c}\text { Straw } \\
\text { yield } \\
\left(\mathrm{t} \mathrm{ha}^{-1}\right)\end{array}$ \\
\hline $\mathrm{M}_{1} \times \mathrm{N}_{1}$ & 113.4 & $265.0 \mathrm{~b}$ & $106.0 \mathrm{~b}$ & 14.6 & 21.9 & $4.30 \mathrm{ab}$ & $5.50 \mathrm{ab}$ \\
\hline $\mathrm{M}_{1} \times \mathrm{N}_{2}$ & 111.4 & $261.3 \mathrm{~b}$ & $103 . .3 \mathrm{~b}$ & 18.0 & 22.0 & $4.20 \mathrm{ab}$ & $5.40 \mathrm{~b}$ \\
\hline $\mathrm{M}_{1} \times \mathrm{N}_{3}$ & 109.2 & $162.0 \mathrm{~h}$ & $79.0 \mathrm{fg}$ & 26.6 & 21.9 & $2.93 \mathrm{~cd}$ & $4.70 \mathrm{~cd}$ \\
\hline $\mathrm{M}_{2} \times \mathrm{N}_{1}$ & 111.0 & $280.0 \mathrm{a}$ & $111.0 \mathrm{a}$ & 14.6 & 22.3 & $4.49 \mathrm{a}$ & $5.70 \mathrm{a}$ \\
\hline $\mathrm{M}_{2} \times \mathrm{N}_{2}$ & 113.1 & $276.0 \mathrm{a}$ & $109.0 \mathrm{a}$ & 16.3 & 22.9 & $4.49 \mathrm{a}$ & $5.60 \mathrm{ab}$ \\
\hline $\mathrm{M}_{2} \times \mathrm{N}_{3}$ & 105.6 & $180.0 \mathrm{~g}$ & $77.0 \mathrm{~g}$ & 28.6 & 21.7 & $2.56 \mathrm{de}$ & $4.73 \mathrm{~cd}$ \\
\hline $\mathrm{M}_{3} \times \mathrm{N}_{1}$ & 102.0 & $230.0 \mathrm{c}$ & $98.3 \mathrm{c}$ & 17.6 & 21.9 & $4.03 \mathrm{ab}$ & $4.90 \mathrm{c}$ \\
\hline $\mathrm{M}_{3} \times \mathrm{N}_{2}$ & 101.6 & $222.0 \mathrm{~d}$ & $89.0 \mathrm{~d}$ & 23.3 & 21.7 & $3.93 \mathrm{~b}$ & $4.83 \mathrm{~cd}$ \\
\hline $\mathrm{M}_{3} \times \mathrm{N}_{3}$ & 95.4 & $198.0 \mathrm{f}$ & $72.3 \mathrm{~h}$ & 31.3 & 21.9 & $2.73 \mathrm{de}$ & $4.73 \mathrm{~cd}$ \\
\hline $\mathrm{M}_{4} \times \mathrm{N}_{1}$ & 102.6 & $205.0 \mathrm{e}$ & $86.0 \mathrm{e}$ & 24.6 & 21.9 & $3.40 \mathrm{c}$ & $4.60 \mathrm{~cd}$ \\
\hline $\mathrm{M}_{4} \times \mathrm{N}_{2}$ & 98.4 & $197.0 \mathrm{f}$ & $80.3 \mathrm{f}$ & 22.3 & 21.5 & $3.23 \mathrm{c}$ & $4.63 \mathrm{~cd}$ \\
\hline $\mathrm{M}_{4} \times \mathrm{N}_{3}$ & 93.1 & $196.0 \mathrm{f}$ & $64.3 \mathrm{i}$ & 33.3 & 21.2 & $2.30 \mathrm{e}$ & $4.56 \mathrm{~d}$ \\
\hline $\mathrm{CV}(\%)$ & 4.59 & 6.64 & 3.34 & 9.34 & 1.69 & 5.16 & 3.74 \\
\hline F-test & NS & $* *$ & $* *$ & NS & NS & $* *$ & $* *$ \\
\hline
\end{tabular}

Note: $\mathrm{M}_{1}=$ BRRI recommended (TPR), $\mathrm{M}_{2}=$ SRI method, $\mathrm{M}_{3}=$ Sprouted seed in line sowing, $\mathrm{M}_{4}=$ Sprouted seed in broadcasting; $\mathrm{N}_{1}=$ BRRI recommended nutrient management, $\mathrm{N}_{2}=$ Soil test based nutrient management, $\mathrm{N}_{3}=$ Control

The maximum straw yield (5.70 $\left.\mathrm{tha}^{-1}\right)$ of rice was recorded in SRI system (9- days old seedling) transplantation along with BRRI recommended fertilizer dose followed by soil test based fertilizer and BRRI recommended transplantation system along with BRRI recommended fertilizer dose. Sprouted seed in broadcasting method along with control fertilizer produced the minimum straw yield $\left(4.56 \mathrm{t} \mathrm{ha}^{-1}\right)$.

\section{Economic Analysis}

Variable cost varied due to the variation of labor number for crop establishment and for different fertilizer doses. The highest variable cost was incurred by the SRI methods ( 9.0 days old seedling transplantation) along with BRRI recommended fertilizer doses (Tk.44,582.00 $\mathrm{ha}^{-1}$ ) while the lowest variable cost was incurred by the sprouted direct seeding in broadcasting method with control fertilizer (Tk. $26725.00 \mathrm{ha}^{-1}$ ). This was similar to the results of Kabir et al. (2009) who found lowest variable cost in direct seeded rice due to the omission of seedling raising, uprooting and transplanting. Similar and highest net return (Tk. $78575.00 \mathrm{ha}^{-1}$ ) was obtained from $\mathrm{M}_{2} \mathrm{~N}_{1}$ and $\mathrm{M}_{2} \mathrm{~N}_{2}$ combinations but maximum gross margin Tk. $36308.00 \mathrm{ha}^{-1}$ and Tk. $35227.00 \mathrm{ha}^{-1}$ and benefit cost ratio and 2.06 and 2.05 was obtained from $\mathrm{M}_{3} \times \mathrm{N}_{1}$ and $\mathrm{M}_{3} \times \mathrm{N}_{2}$ combinations, respectively due to direct seeded rice is both cost- and labor-saving, although grain yield in direct seeded rice is comparatively less than that of transplanted rice. 
Table 4. Economic performances of crop establishment methods and fertilizer management on yield of short duration Aman rice variety

\begin{tabular}{lccccc}
\hline Interaction & $\begin{array}{c}\text { Grain yield } \\
\left(\mathrm{t} \mathrm{ha}^{-1}\right)\end{array}$ & $\begin{array}{c}\text { Total cost } \\
\left(\text { Tk. ha }^{-1}\right)\end{array}$ & $\begin{array}{c}\text { Gross return } \\
\left(\text { Tk. ha }^{-1}\right)\end{array}$ & $\begin{array}{c}\text { Gross margin } \\
\left(\text { Tk. ha }^{-1}\right)\end{array}$ & BCR \\
\hline $\mathrm{M}_{1} \times \mathrm{N}_{1}$ & 4.30 & 41167 & 75250 & 34083 & 1.83 \\
$\mathrm{M}_{1} \times \mathrm{N}_{2}$ & 4.20 & 40498 & 73500 & 33002 & 1.81 \\
$\mathrm{M}_{1} \times \mathrm{N}_{3}$ & 2.93 & 36450 & 51275 & 14825 & 1.41 \\
$\mathrm{M}_{2} \times \mathrm{N}_{1}$ & 4.49 & 44582 & 78575 & 33993 & 1.76 \\
$\mathrm{M}_{2} \times \mathrm{N}_{2}$ & 4.49 & 43913 & 78575 & 34662 & 1.79 \\
$\mathrm{M}_{2} \times \mathrm{N}_{3}$ & 2.56 & 39865 & 44800 & 4935 & 1.12 \\
$\mathrm{M}_{3} \times \mathrm{N}_{1}$ & 4.03 & 34217 & 70525 & 36308 & 2.06 \\
$\mathrm{M}_{3} \times \mathrm{N}_{2}$ & 3.93 & 33548 & 68775 & 35227 & 2.05 \\
$\mathrm{M}_{3} \times \mathrm{N}_{3}$ & 2.73 & 29500 & 47775 & 18275 & 1.62 \\
$\mathrm{M}_{4} \times \mathrm{N}_{1}$ & 3.40 & 31442 & 59500 & 28058 & 1.89 \\
$\mathrm{M}_{4} \times \mathrm{N}_{2}$ & 3.23 & 30773 & 56525 & 25752 & 1.84 \\
$\mathrm{M}_{4} \times \mathrm{N}_{3}$ & 2.30 & 26725 & 40250 & 13525 & 1.51 \\
\hline
\end{tabular}

Grain price: Tk. $16.75 \mathrm{~kg}^{-1}$

\section{Conclusion}

From the results of the study, it can be concluded that short-duration Aman variety BRRI dhan62 performed better under SRI and BRRI recommended transplantation method along with BRRI recommended fertilizer doses than other methods in terms of grain yield. From the economic point of view, the cultivation of BRRI dhan62 with direct seeding of spouted seed in line can be recommended for reducing the production cost.

\section{References}

Amin, M., M. A. Khan, E. A. Khan and M. Ramzan. 2004. Effect of Increased plant density And Fertilizer dose on the yield of rice variety Ir-6. J. Res. Sci. 15(1): 9-16

Balasubramanian, V, J. E. Hill. 2002. Direct seeding of rice in Asia: emerging issues and strategic research needs for the $21^{\text {st }}$ century. In: Pandey S, Mortimer M, Wade L, Tuong TP, Lopez K, Hardy B, eds. direct seeding: research strategies and opportunities. Los Ban os, The Philippines: International Rice Research Institute, Pp. 15-39.

Chauhan, B. S., G. Mahajan, V. Sardana, J. Timsina and M. L. Jat. 2012. Productivity and sustainability of the rice-wheat cropping system in the Indo-Gangetic Plains of the Indian subcontinent: problems opportunities, and strategies. Adv. Agron. 117: 315-369.

FRG. 1997. Fertilizer Recommendation Guide, Bangladesh Agricultural Research Council, Farmgate, Dhaka. p.185.

Gomez, A. A. and A. A. Gomez. 1984. Statistical procedures for Agricultural Research. John Wiley and Sons. New York. pp. 207-215.

Hassan, A. and K. Behzad. 2011. Assessment of direct seeded and transplanting methods of rice cultivars in the northern part of Iran. African J. Agril. Res. 6 (31): 6492-6498 
Husain, A. M. M., P. Barua, and S. R. Halder. 2003. Verification and refinement of the System of Rice Intensification (SRI) project in selected areas of Bangladesh. Trial Monitoring Survey Report on Chatkhil and Begumgonj in Noakhali District. BRAC.

Hussain, A. M. M., G. Chpwhan, A. B. M. Z. Rahman, R. Uddin and P. Barua. 2004. Report on the system of rice intensification. PETRRA technology workshop, BRRI Auditorium, Gazipur.

IRRI. 1978. International Rice Research Institute Annual report. International Rice Research Institute. Los Banos, Philippines.

Kabir, M. H., M. S. U. Bhuiya, A. Saha, M. A. H. Khan and N. E. Elahi. 2009. Effect of Crop Establishment Method and Time of Nitrogen Application on the Productivity of Boro Rice in Lowland Ecosystem. Bangladesh Rice Journal, 14(1-2) pp. 1-6.

Kim, S. S., B. K. Kim, M. G. Choi, N. H. Back, W. Y. Choi and S. Y. Lee. 1999. Effect of seedling age on growth and yield on machine transplanted rice in Southern plain region. Korean J. Crop Sci. 44(2): 122-128.

Krishna, A. and N. K. Biradarpatil. 2009. Influence of seedling age and spacing on seed yield and quality of short duration rice under system of rice intensification cultivation. Karnataka J. Agric. Sci. 22(1): 53-55

Quayum, M. A., A. M. Ali, M. A. Salam. 2012. Impact of power tillers on profitability of some cropping patterns in some selected areas of Bangladesh. Bangladesh. J. Agric.Res. 37: 415432. 